\title{
Comparison of the Argon Triple-Point Temperature in Small Cells of Different Construction
}

\author{
B. Kołodziej ${ }^{1}(\mathbb{D}) \cdot$ A. Kowal $^{1} \cdot$ L. Lipiński $^{1}$. \\ H. Manuszkiewicz ${ }^{1}$ - A. Szmyrka-Grzebyk ${ }^{1}$
}

Received: 29 August 2016 / Accepted: 27 March 2017 / Published online: 13 April 2017

C The Author(s) 2017. This article is an open access publication

\begin{abstract}
The argon triple point $\left(T_{90}=83.8058 \mathrm{~K}\right)$ is a fixed point of the International Temperature Scale of Preston-Thomas (Metrologia 27:3, 1990). Cells for realization of the fixed point have been manufactured by several European metrology institutes (Pavese in Metrologia 14:93, 1978; Pavese et al. in Temperature, part 1, American Institute of Physics, College Park, 2003; Hermier et al. in Temperature, part 1, American Institute of Physics, College Park, 2003; Pavese and Beciet in Modern gas-based temperature and pressure measurement, Springer, New York, 2013). The Institute of Low Temperature and Structure Research has in its disposal a few argon cells of various constructions used for calibration of capsule-type standard platinum resistance thermometers (CSPRT) that were produced within 40 years. These cells differ in terms of mechanical design and thermal properties, as well as source of gas filling the cell. This paper presents data on differences between temperature values obtained during the realization of the triple point of argon in these cells. For determination of the temperature, a heat-pulse method was applied (Pavese and Beciet in Modern gas-based temperature and pressure measurement, Springer, New York, 2013). The comparisons were performed using three CSPRTs. The temperatures difference was determined in relation to a reference function $W(T)=R\left(T_{90}\right) / R(271.16 \mathrm{~K})$ in order to avoid an impact of CSPRT resistance drift between measurements in the argon cells. Melting curves and uncertainty budgets of the measurements are given in the paper. A construction of measuring apparatus is also presented in this paper.
\end{abstract}

Selected Papers of the 13th International Symposium on Temperature, Humidity, Moisture and Thermal Measurements in Industry and Science.

$凶 \quad$ B. Kołodziej

B.Kolodziej@int.pan.wroc.pl

1 Instytut Niskich Temperatur i Badań Strukturalnych PAN, Wrocław, Poland 
Keywords Argon triple point · Comparison · CSPRT · ITS-90

\section{Introduction}

The argon triple point $\left(T_{90}=83.8058 \mathrm{~K}\right)$ is a definitional fixed point of the International Temperature Scale of 1990 . For realization of the point, miniature cells that contained high-purity argon, under a high pressure near $10 \mathrm{MPa}$ at room temperature, can be used [6]. The temperature of argon during the transition realization in the miniature cells is measured with CSPRTs. Various types of sealed cells were manufactured and implemented for the realization of the triple point of argon within 40 years in several metrology institutes. An internal construction and a filling method are the main differences between these devices. Five miniature argon sealed cells manufactured at different metrology institutes-IMGC/INRiM in Italy, BNM/LNE-LNE-Cnam (France) and VNIIFTRI (Russia) are currently used at INTiBS.

The temperature differences of the phase transition realized in these cells were determined during the experiment. The phase transition of argon was performed under nearly adiabatic conditions, using a home-made cryostat cooled with liquid nitrogen.

\section{Argon Cells}

Numbers of the tested argon cells and their producers are presented in Table 1.

The cells construction, suppliers of the gas used for filling the cell and the methods of filling were different. Some important details of the constructions are presented in Fig. 1.

Preliminary tests showed that all cells contain argon and the amount of the gas was sufficient to realize the fixed point correctly. In the case of cells I,III, IV and V, the copper heat exchangers for realization of a thermal contact between the cell and CSPRTs were made (see Fig. 1). The heaters made of a high-resistivity wire were attached to the heat exchangers (cells I and III) or to the cell wall (cells II, IV and $\mathrm{V})$. The heater was used to increase the cell temperature up to the triple point after freezing of the argon. The heater controlled by an electronic system allows to melt the substance in a controlled manner by putting the energy in a form of heat pulses while realizing the phase transition.

Table 1 The tested argon triple-point cells

\begin{tabular}{lll}
\hline Cell & Number & Manufacturer \\
\hline I & E5Ar-2001 & IMGC-CNR (now is INRIM), Italy \\
II & 3 Ar-6-V-86 & \\
III & Ar05/3 & BNM-INM (now is LNE-Cnam), France \\
IV & Ar01-2 & \\
V & 796 & VNIIFTRI, Russia \\
\hline
\end{tabular}




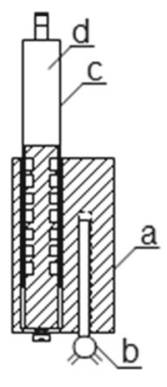

I

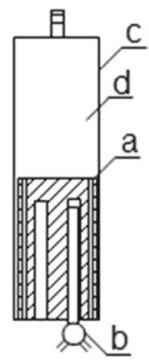

II

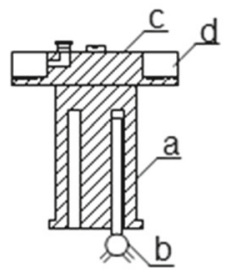

III, IV

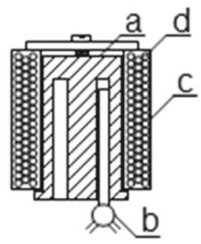

V

Fig. 1 Construction of the argon triple-point cells; (a)—-heat exchanger, (b) —CSPRT, (c) — cell wall, (d)— argon chamber

Fig. 2 Construction of the liquid nitrogen cryostat;

(a)—argon cell, (b) - CSPRT,

(c)_vacuum chamber,

(d) - thermal shields,

(e)_plastic thread

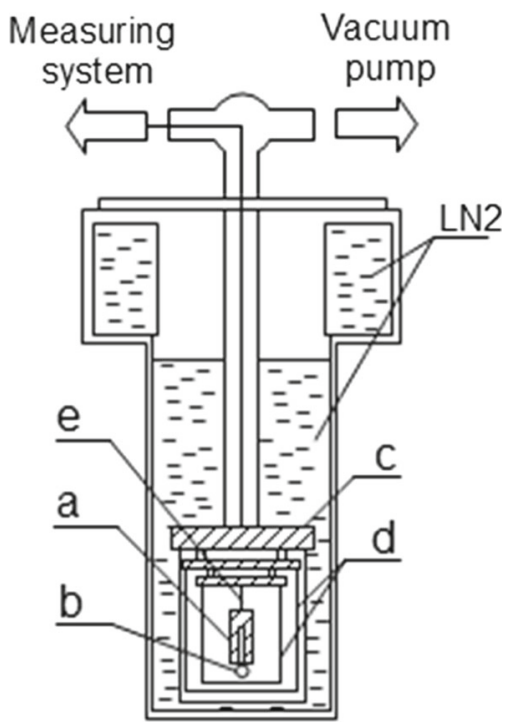

A construction of the home-made cryostat used for the comparisons is presented in Fig. 2. The cryogenic equipment is an element of the Polish National Temperature Standard in the range $13.8033 \mathrm{~K}$ to $273.16 \mathrm{~K}$ [7]. During the experiment, the argon cell (a) with CSPRT (b) was placed in the vacuum chamber (c) in the cryostat. The chamber construction and the method of performing the experiment ensure near adiabatic conditions in the cryostat chamber. The cell was surrounded by two thermal shields (d) with controlled temperature. The temperature of the internal shield was set near the argon triple-point temperature, therefore reducing the parasitic heat transfer between the cell and outer environment. The cell was attached to the internal shield with the plastic thread (e). The cryostat was cooled down with liquid nitrogen.

For temperature measurements, the following CSPRTs were used: Tinsley no. 217987, CHINO RS158-05 and CHINO RS158-06. The temperature measurements in the cells I-IV were performed with three thermometers, and in the cell V, two 
Fig. 3 Temperature differences

$\Delta T_{\mathrm{TPW}}$ at the triple point of water; •-Tinsley 217987 , ○-CHINO 158-05, $\mathbf{- C H I N O}$ 158-06

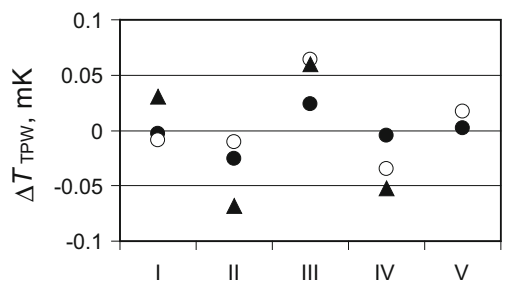

thermometers only could be used because of the heat exchanger construction. The resistance of the thermometers was measured using the FLUKE 1595A SuperThermometer ratio bridge. The Tinsley $25 \Omega$ resistor $R_{S}$, placed in a thermostat, was used as a standard resistor.

\section{Experiment}

Before the comparison and after measurements performed in the argon cells, the resistance $R_{\text {TPW }}$ of each CSPRTs was measured at the triple point of water. The temperature differences $\Delta T_{\mathrm{TPW}}=\left(R_{\text {before }}-R_{\text {after }}\right) \mathrm{d} T / \mathrm{d} R$ are presented in Fig. 3. It should be noted that the thermometers demonstrated a high stability of their characteristics.

Initially the argon cell was cooled to the liquid nitrogen temperature in order to freeze the substance. Cooling was performed by filling the vacuum chamber of the cryostat with gaseous helium, used as a heat switch between the cell and liquid nitrogen. After freezing the argon helium was pumped out and the temperature of the thermal shields was increased to the required value. Thereafter, the cell was heated to reached the temperature value closed to the argon triple point $\left(T_{\mathrm{TPAr}}\right)$. The beginning of the phase transition of argon (beginning of melting) was identified as a beginning of the plateau on the CSPRTs resistance curve. Measurement of the CSPRTs resistance $R_{\mathrm{T}}(F)$ was performed as a function of percentage of melted argon in the cell:

$$
F=\frac{m_{\text {liquid } A r}}{m_{\text {total } A r}}
$$

where $m_{\text {liquid Ar }}$ means the amount of melted fraction and $m_{\text {total Ar }}$ - the total amount of argon in the cell. The heat-pulse method was applied for determination of the melting curves [5]. This method is based on applying heat pulses of known energy to the cell. The amount of energy during the heat pulse was chosen individually for every cell. One pulse gives the energy equal to the 5\%-10\% of the whole phase transition heat of the argon in the cell. After every pulse, time delay needed for stabilization of the cell temperature was applied. The CSPRT resistance value was measured in stable conditions, when the observed thermal drift was less than $0.1 \mathrm{mK}$. The resistance of CSPRT for the given $F$ value was a mean of 200 measurements. During the measurement of each cell, the total amount of argon contained in a cell was melted up to the value $F=1$.

The melting curves registered by the Tinsley 217987 CSPRT in all tested argon cells are presented in Fig. 4. 


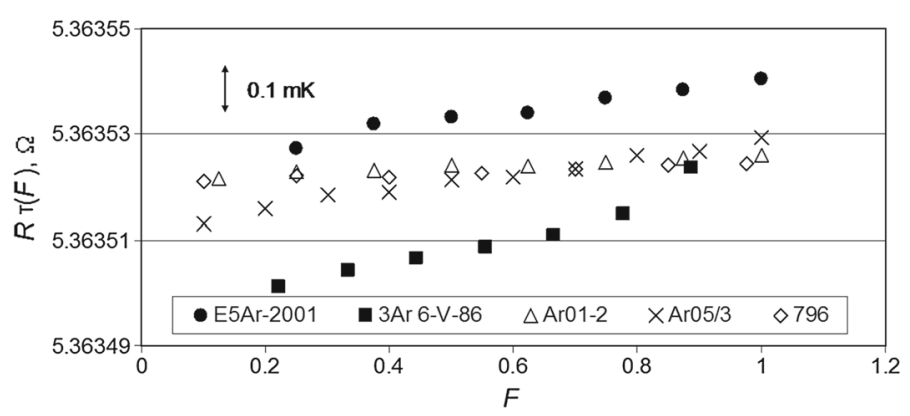

Fig. 4 Melting plateaux of the argon in the tested cells

Fig. 5 Determining

$R_{\mathrm{T}}\left(I_{\mathrm{T}}=0\right)$

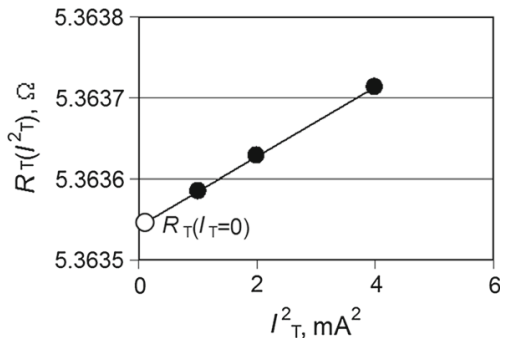

Then, the value $R_{\mathrm{T}}$ for $F=0.5$ was taken to the further analysis.

To eliminate a self-heating effect of thermometer with the measurement current, the value $R_{\mathrm{T}}$ for $I_{\mathrm{T}}=0$ was determined. CSPRT resistance was measured for three currents values: $1 \mathrm{~mA}, \sqrt{ } 2 \mathrm{~mA}$ and $2 \mathrm{~mA}$. Then the linear regression function was applied, and the value $R_{\mathrm{T}}\left(I_{\mathrm{T}}=0\right)$ was estimated. The method of determining $R_{\mathrm{T}}\left(I_{\mathrm{T}}=\right.$ 0 ) is presented in Fig. 5.

The determination of the temperatures difference $\Delta T_{\mathrm{W} \text {, xy }}$ between the argon cells was the main result of the comparison. The $\Delta T_{\mathrm{W}, \mathrm{xy}}$ value for the $x-$ th cell measured by $y$ thermometer is defined as:

$$
\Delta T_{W, x y}=\left(R_{W, x y}-R_{W m e a n, y}\right) \frac{d T}{d R}
$$

where $R_{\mathrm{W} \text {,xy }}$ means $y$ CSPRT resistance in the $x$-th cell and $R_{\text {Wmean,y }}$ stands for the mean resistance value of the $y$ CSPRT determined in all cells. The $\mathrm{d} T / \mathrm{d} R$ value is the sensitivity of the platinum thermometers equal to $10 \mathrm{~K} / \Omega$ at the $T_{\mathrm{TPAr}}$ temperature. Both values $-R_{\mathrm{W}, \mathrm{xy}}$ and $R_{\mathrm{Wmean}, \mathrm{y}}$-were determined for $F=0.5$. The $R_{\mathrm{W}, \mathrm{xy}}$ and $R_{\mathrm{Wmean}, \mathrm{y}}$ values included the influence of the CSPRT drift. The $R_{\mathrm{W}, \mathrm{xy}}$ is defined as:

$$
R_{W, x y}=\frac{R_{x, y}\left(T_{A r}\right)}{R_{y}\left(T_{T P W}\right)} R_{y, \text { mean }}\left(T_{T P W}\right)
$$

where $R_{\mathrm{x}, \mathrm{y}}\left(T_{\mathrm{Ar}}\right)$ is the $y$ CSPRT resistance in $x$-th cell at $T_{\mathrm{TPAr}} \cdot R_{\mathrm{y}}\left(T_{\mathrm{TPW}}\right)$ is the $y$ CSPRT resistance at $T_{\mathrm{TPW}}$ and $R_{\mathrm{y}, \text { mean }}\left(T_{T P W}\right)$ the mean $y$ CSPRT resistance in all 
Table $2 \Delta T_{\mathrm{W}}$ value for the cells I-V

\begin{tabular}{lc}
\hline Cell & $\Delta T_{\mathrm{W}}, \mathrm{mK}$ \\
\hline I & 0.15 \\
II & -0.16 \\
III & 0.00 \\
IV & -0.04 \\
V & 0.00 \\
\hline
\end{tabular}

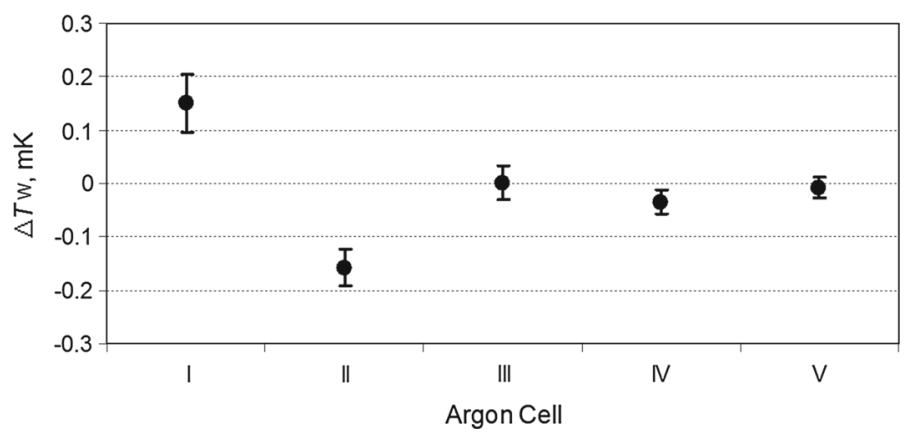

Fig. $6 \Delta T_{\mathrm{W}}$ value for the cells I-V

Table $3 \Delta T_{\mathrm{W}}$ uncertainty budgets for the cells I-V, component values in $\mu \mathrm{K}$

\begin{tabular}{lrrrrr}
\hline Uncertainty component & \multicolumn{2}{l}{ Cell } & & & \\
\cline { 2 - 6 } & I & II & III & IV & V \\
\hline Static thermal effect & 50 & 15 & 22 & 20 & 15 \\
Dynamic thermal effect & 5 & 5 & 10 & 5 & 10 \\
Reproducibility of thermometer & 2 & 2 & 2 & 2 & 2 \\
Determination of $F=0.5$ & 18 & 30 & 17 & 5 & 4 \\
Measurement noise & 6 & 4 & 9 & 5 & 6 \\
$\mathrm{R}_{\text {S }}$ thermal drift & 4 & 4 & 4 & 4 & 4 \\
Combined standard uncertainty & 54 & 35 & 31 & 22 & 20 \\
\hline
\end{tabular}

cells, defined as:

$$
R_{W m e a n, y}=\frac{1}{5} \sum_{X-I}^{V} R_{W, x y}
$$

The $\Delta T_{\mathrm{W} \text {,xy }}$ values were determined independently for each thermometer. $\Delta T_{\mathrm{W}}$ values are determined as the mean value indicated by all thermometers in individual cells. $\Delta T_{\mathrm{W}}$ values are presented in Table 2 and shown in Fig. 6.

Table 3 presents the uncertainty budget for the $\Delta T_{\mathrm{W}}$ values determination. The uncertainty components were estimated in accordance with the guidelines published in [8]. 


\section{Conclusion}

The results presented in this paper refers to the argon triple-point cells of a different construction that were manufactured in three metrology institutes during last 40 years. Differences in the construction of the cells have a noticeable impact on their thermal resistance and in consequence have an influence on the static thermal effect uncertainty component. The maximum value of this component is observed for the cell I (E5Ar2001). In the cell, a thermal contact between the thermometer and the cell is realized on a small surface.

The largest plateau width equal to $0.12 \mathrm{mK}$ for $F$ between 0.2 and 0.8 was observed in cell II. The smallest value $(0.02 \mathrm{mK})$ was observed for cell $\mathrm{V}$. This may be due to the fact that the cell was filled with the gas of the highest purity.

The maximum difference of the argon triple-point temperature realized in all cells was lower than $0.31 \mathrm{mK}$ with standard uncertainty $u(\Delta T)=0.07 \mathrm{mK}$. Neither manufacturing date nor the method of filling of the cells affects a significant change in the temperature of the triple point. This confirms that the production process of all cells maintains appropriate technological conditions

Acknowledgements The work was realized with a financial support of the National Centre of Research and Development NCBiR within the Grant PBS1/A9/6/2012.

Open Access This article is distributed under the terms of the Creative Commons Attribution 4.0 International License (http://creativecommons.org/licenses/by/4.0/), which permits unrestricted use, distribution, and reproduction in any medium, provided you give appropriate credit to the original author(s) and the source, provide a link to the Creative Commons license, and indicate if changes were made.

\section{References}

1. H. Preston-Thomas, Metrologia 27, 3 (1990)

2. F. Pavese, Metrologia 14, 93 (1978)

3. F. Pavese, D. Ferri, I. Peroni, A. Pugliese, P.P.M. Steur, B. Fellmuth, D. Head, L. Lipinski, A. Szmyrka-Grzebyk, L. Wolber, Temperature, part 1, vol. 7 (American Institute of Physics, College Park, 2003)

4. Y. Hermier, L. Pitre, C. Geneville, A. Verge, G. Bonnier, D.I. Head, B. Fellmuth, L. Wolber, A. SzmyrkaGrzebyk, L. Lipinski, M.J. de Groot, A. Peruzzi, Temperature, part 1, vol. 7 (American Instistute of Physics, College Park, 2003)

5. F. Pavese, G.M.M. Beciet, Modern Gas-Based Temperature and Pressure Measurement, 2nd edn. (Springer, New York, 2013)

6. F. Sparasci, L. Pitre, G. Rouillé, J.-P. Thermeau, D. Truong, F. Galet, Y. Hermier, Int. J. Thermophys. 32, 201 (2011)

7. A. Szmyrka-Grzebyk, L. Lipiński, H. Manuszkiewicz, A. Kowal, A. Grykałowska, D. Jancewicz, Int. J. Thermophys. 32, 2466 (2011)

8. D.R. White et al., Uncertainties in the Realisation of the SPRT Subranges of the ITS-90, CCT/0819/rev, CCT WG3: July 2009, http://www.bipm.org/cc/CCT/Allowed/24/D19_rev_WG3_Doc_rev_ 10July2009.pdf 